\title{
Ewa Stawicka
}

\section{Social responsibility}

and relations with employees

in the aspect of a family business

Summary: The main aim of the article is to present a theoretical reflection, based on the literature on the subject, on the development, opportunities, and threats of social responsibility in the family business sector (small and medium-sized enterprises sector). The article focuses on Goal 8 Decent work and economic growth. In practical terms, based on empirical research, including those conducted by the Responsible Business Forum, good practices in the area of employees and CSR solutions in the family business sector were assessed. The study also took into account other results of previous research on aspects related to good practices for employees and CSR in SME enterprises. As part of the study, specific opportunities and threats were identified in the aspect of implementing CSR solutions in the area of employees and towards sustainable development. The results of the survey show that many entrepreneurs in the SME sector still implement too few solutions in the field of CSR strategies towards sustainable development and the area of employees. The article indicates many useful and practical solutions that may affect the implementation of specific CSR strategies towards sustainable development and the improvement of the condition and good practices in the area of employees.

The article presents selected research results concerning various aspects of human capital management in the SME sector. Recommendations for improving good practices in terms of employees were indicated, which may also improve economic results and create a competitive advantage in terms of sustainable development.

Keywords: social responsibility, sustainability, human capital, family business

\section{Odpowiedzialność spoleczna i relacje z pracownikami w kontekście firmy rodzinnej}

Streszczenie: Głównym celem artykułu jest przedstawienie refleksji teoretycznej, na podstawie literatury przedmiotu, dotyczącej rozwoju, szans i zagrożeń społecznej odpowiedzialności w sektorze przedsiębiorstw rodzinnych (sektor małych i średnich przedsiębiorstw). W artykule zwrócono szczególną uwagę na cel 8 Godna praca i wzrost ekonomiczny. W aspekcie praktycznym na podstawie badań empirycznych, między innymi 
prowadzonych przez Forum Odpowiedzialnego Biznesu, ocenie poddano dobre praktyki w obszarze „pracownicy” oraz rozwiązania i praktyki z zakresu społecznej odpowiedzialności w sektorze przedsiębiorstw rodzinnych. W ramach badania zidentyfikowano szanse i zagrożenia w aspekcie wdrażania rozwiązań CSR w obszarze pracownicy i w kierunku zrównoważonego rozwoju. Wyniki badania wskazują, że wiele przedsiębiorców w sektorze MŚP (firm rodzinnych) wdraża wciąż zbyt mało rozwiązań z zakresu strategii CSR w kierunku zrównoważonego rozwoju i w obszarze „pracownicy”. W artykule wskazano na użyteczne i praktyczne rozwiązania, które mogą wpływać na wdrażanie strategii CSR w kierunku zrównoważonego rozwoju oraz poprawę stanu i dobrych praktyk w obszarze pracownicy.

W artykule przedstawiono wybrane wyniki badań dotyczących różnych aspektów zarządzania kapitałem ludzkim w sektorze MŚP. Wskazano rekomendacje usprawnienia dobrych praktyk w aspekcie pracowników, co wpływać może na poprawę wyników ekonomicznych i tworzenia przewagi konkurencyjnej w aspekcie zrównoważonego rozwoju.

Słowa kluczowe: społeczna odpowiedzialność, zrównoważony rozwój, kapitał ludzki, biznes rodzinny

JEL: A13, M5, O35

\section{Introduction}

Sustainable development is multifaceted. A feature of the idea is the balancing of the basic elements shaping the future of human society on Earth, i.e. the environment, society, and economy so that the development of one element does not pose a threat to others.

Corporate social responsibility (CSR) occupies an increasingly high position among the priorities of corporate policy. The importance of conscious choices and behaviors towards sustainable development and business management is emphasized in such a way as to analyze its impact on social life. The implementation of corporate social responsibility standards is also part of the strategic documents for the development of Europe, the implementation of the 2030 Agenda $^{1}$. Along with publicizing the Sustainable Development Goals (SDGs), managers in various companies are looking for specific solutions so that business activities contribute directly to combating social inequalities, counteracting climate change, reducing resource waste and promoting responsibility ${ }^{2}$. To some extent, this necessitates the involvement of entrepreneurs in environmental and social issues to strengthen stability and act towards the social good in the long term. In practice, however, it turns out that entrepreneurs react solidly or with a complete makeshift to social expectations regarding the processes and effects of taking responsibility.

According to L.K. Weaver et al. ${ }^{3}$ makeshift structures and action programs seem to meet the expectations of the environment and lead to anesthesia of these expectations.

\footnotetext{
Serwis Rzeczypospolitej Polskiej, Agenda 2030.

CSR Consulting (2016), SDGs w praktyce, CSR Consulting, s.5.

ibidem.
} 
And although structures and strategies of operation exist, there is no guarantee that they will harmonize with other enterprises and structures of the company, and that employees will feel responsible. It is true, however, that business motivation towards corporate social responsibility is more often the practice of large companies or corporations. In the case of the SME sector, the phenomenon is rather unknown and not fully accepted. On the other hand, the initiatives of the NGOs themselves are not able to force too much change in awareness and approach to CSR. There are also too few informed stakeholders who force entrepreneurs to change their behavior on the market.

The dynamics of economic changes and the large size of social needs increasingly require a new development paradigm and the involvement of all stakeholders in active cooperation. There are changes in social attitudes, awareness increases, and employee attitudes on the labor market change. Analyzing data on issues covered in the 2030 Agenda, no country is on the fast track to achieving all Sustainable Development Goals ${ }^{4}$. In Poland, the greatest emphasis is placed on goals 9, 12, 13 .

The aim of the article is a theoretical reflection on the development, opportunities and threats to social responsibility in the sector of small and medium enterprises. The article paid special attention to goal 8, Decent Work and Economic Growth. Good practices in the area of employees in the aspect of CSR in the family business sector were assessed.

The article is organized as follows. The first part of the article briefly outlines the motivation for this research and the purpose of this article. The second section contains a very brief theoretical basis, an integrated framework of factors influencing CSR, sustainable development, and human capital in family businesses. The following chapters contain the presentation and discussion of practical results based on the literature review. The article ends with a discussion and final remarks. The article is a theoretical contribution to further research in the aspect of the impact of family businesses on the implementation of sustainable development goals.

\section{CSR and the individual perspective of a man}

Behind every decision or behavior in the organization is a man. The external world of man is a reflection of the internal world of thoughts, feelings, and beliefs. Before corporate social responsibility begins, personal social responsibility should appear. From the point of view of corporate social responsibility, investing in responsible solutions towards the individual, often the employee allows supporting the physical and mental health of employees 5 .

The essence of human work takes on a new and different value. On the one hand, there are generational and mental changes of contemporary generations, and on the other hand, socio-economic changes are becoming rapid. The high requirements for employees are dictated by expectations of the knowledge society. According to D. Kukel ${ }^{6}$, work becomes

Marchlewicz M. (2020), 5 lat SDGs w Polsce, raport Odpowiedzialny Biznes w Polsce, 2019, FOB, s.14.

Lewandowska-Akhvlediani S. (2011), CSR a cztowiek jako jednostka, w: Ustugi spoteczne odpowiedzialnego biznesu, Wyższa Szkoła Pedagogiczna, Warszawa, s.106-153.

6 Kukla D. (2016), Wspótczesne spoteczeństwo w kontekście kreowania rynku pracy, "Szkoła, Praca, Zawód", nr 11, Bydgoszcz, s.63-72. 
an indicator of prestige, the ability to secure material status (which is extremely important during consumerism). The possibility of personal and professional development becomes important.

However, M. Strykowska emphasizes the transformations of the essence of human work. The author points out that:

- more and more emphasis is placed on flexible work, allowing for the quick response;

- important ways of communicating people are changing, and some of them (e.g. via computer) are devoid of both emotions and non-verbal indicators,

- work is increasingly based on cooperation and cooperation,

- the approach to work becomes more fluid (e.g. smooth working hours, split work, part-time work),

- individuals' aspiration to increase job satisfaction by changing its content is becoming increasingly important,

- the number of employees having the status of a permanent employee decreases, the percentage of those employed on a part-time basis increases,

- the era of so-called linear careers beginning with education, employment, gradual promotion to retirement?

Personal social responsibility is the ability to look at yourself and the world from a broader perspective, in which, when realizing your personal goals, the expectations and needs of other social and professional life partners are taken into account.

Everyone fulfills specific needs, also in the work environment needs should be met. This helps to achieve organizational commitment, job satisfaction, internal ties with other employees. It also allows each person to be prepared for possible crisis activities from their perspective.

Economy 4.0 and job forecasts also indicate that most future jobs will need human feelings, thinking, empathy and imagination. There are virtually no rational reasons to fear that machines will wipe people out because they are not and will not be people. However, there will be a chance to free people from tiring, monotonous, boring, and stressful jobs, taking time where they could use it more creatively ${ }^{8}$. The development of human needs is very accurately characterized by the hierarchy of needs according to Abraham Maslow. And A.B. Carrol has also described the responsible business model in the form of a pyramid and levels of needs ${ }^{9}$. It indicates the development of the philosophy of responsibility in enterprises as part of the development of functioning. New corporate social responsibility models show increasingly balanced approaches and are evolving. Also other models,

Strykowska M. (2001), Globalizacja a kariera zawodowa, w: Spoteczne problemy globalizacji, red. Z. Blok, Wyd. Naukowe UAM, Poznań, s.43-44.

8 Gerlach R. (2019), Organizacja przysztości w perspektywie czwartej rewolucji przemystowej i spoteczeństwa 5.0, w: red. nauk. R. Tomaszewska, Barwy codzienności, UKW, Bydgoszcz, s.63.

9 Caroll A.B. (1991), The Pyramid of Corporate Social Responsibility: Toward the Moral Management of Organizational Stakeholders, "Business Horizons". 
Wartica and Cochrana $(1985)^{10}$, D.J. Wood $(1991)^{11}$, 3C-SR model (Meehan, 2006) ${ }^{12}$, LBG model ${ }^{13}$, ISO $26000^{14}$ Guidelines for the implementation of corporate social responsibility in organizations, 17 Sustainable Development Goals (SDGs) and others set new business paradigms. Especially thanks to SDGs, business gains new social innovations, development paths, consolidates the model of building sustainable, long-term, innovative and with the involvement of more and more aware and responsible consumers, competitive advantage. Sustainable development goals are creating the value of enterprises as:

- a source of development for new products, services, technologies, and distribution channels - stimulated by newly defined needs and services, also for people on low incomes, and choices of conscious consumers preferring products of socially responsible companies;

- promoting a sustainable supply chain - responsible practices are an incentive to cooperate with suppliers who adhere to the highest standards of ethics and sustainable development;

- a stable framework for political decisions, creating stable development opportunities and creating long-term strategies;

- the possibility of multilateral partnerships, strengthening relationships with stakeholders towards key business topics;

- stabilization of markets and societies as a possibility of predicting behavior and phenomena and thus striving to reduce business risk;

- increasing social commitment, employee involvement, loyalty, new employee competencies ensuring professional and personal satisfaction as well as stronger relationships with clients translating into higher productivity ${ }^{15}$.

\section{A new approach to improving competitiveness in family businesses}

The implementation of the idea of corporate social responsibility combines economic and social interest and thus can bring many different benefits to an enterprise. These include, among others: better financial results, increased productivity, employee involvement, increased brand value and improved company reputation, access to information, reduced response time, and reduced operating costs. The development of the concept of CSR, whose dimension is, inter alia, the pursuit of the development of human capital, undertaking activities friendly to the natural environment, development of social sensitivity and civic attitudes, should permanently translate into strengthening the position of enterprises, which

10 Wartick S.L., Cochran P.L. (1985), The evolution of the Corporate Social Performance Model, "Academy of Management Review”, Vol.10, Nr 4.

11 Wood D.J. (1991), Corporate Social Performance Revisited, “Academy of Management Review”, Nr 4.

12 Meehan J., Meehan K., Richards A. (2006), Corporate Social Responsibility, The 3C-SR model, "International Journal of Social Economics”, Vol 33, Nr 5/6, s.392.

13 LBG (2014), Guidance manual from inputs to impact-measuring corporate community contributions through the $L B G$ framework, "Corporate Citizenship", London.

14 PN-ISO 26000 (2012), Wytyczne dotyczące spotecznej odpowiedzialności, Polski Komitet Normalizacyjny, Warszawa, listopad.

15 Liczmańska-Kopcewicz K., Mizera K., Pypłacz P. (2019), Corporate Social Responsibility and Sustainable Development for Creating Value for FMCG Sector Enterprises, "Sustainability", 11(20), s.5808. 
is based on increased competitiveness. Dynamically occurring changes in the environment, development of new technologies, changes in customer preferences, and differences in the needs and expectations of partners mean that enterprises are forced to constantly respond to external stimuli and adapt to the environment. In addition to their core business, i.e. making a profit, enterprises have to deal with problems arising in virtually every area of activity. The more that because since the negative impact of business on the environment and its impact on social, economic, and ecological problems is increasingly seen. There is a widespread belief that companies thrive at the expense of larger communities. Enterprises are increasingly accounted for the social and environmental consequences of their activities with each passing day. As a result, many companies begin to implement and develop the concept of corporate social responsibility. A social and responsible approach becomes not only the norm but also the priority of the activity. However, the way CSR programs are introduced and implemented is extremely important.

When talking about corporate social responsibility, one should keep in mind the way and approach of a given company to implementing and acting by following per under the principles of this concept. The benefits of running a socially responsible business depend on the level of involvement of society. One can speak of imposed responsibility when the company merely limits itself to complying with applicable law, whether in social or environmental terms ${ }^{16}$.

We can also distinguish forced responsibility, e.g. public pressure, which largely depends on the successful operation of a given company on the market. The company's attitude in the field of responsible business may, however, result from voluntary awareness and a sense of concern for the social and economic development of the region. Then we can talk about the highest real benefits that the enterprise itself, as well as the whole society, benefits from ${ }^{17}$.

Therefore, proper and full implementation of the concept of corporate social responsibility can only be talked about when enterprises do something that goes beyond applicable law ${ }^{18}$. When presenting the benefits of implementing the concept of corporate social responsibility, one should point out such issues as publicizing and solving important social problems, educating the society, contributing to social activation, promoting benevolent attitudes, stimulating economic development, and increasing the wealth of citizens, improving the environment. Enterprises to meet social expectations often change the way and scope of business operations and the entire organizational culture, which can have a positive impact on the company's image, and above all the financial result ${ }^{19}$.

Voluntary business initiatives promote higher standards of ethical conduct, translate into the additional market value of the company, build customer confidence, increase investor interest, and are a reason for employees' pride.

\footnotetext{
16 Łukasiński W. (2010), Aspekt ekologiczny w koncepcji spotecznej odpowiedzialności przedsiębiorstwa, „Ekonomika i Organizacja Przedsiębiorstwa”, nr 10, s.10-18.

17 Marcinkowska M. (2010), Spoteczna odpowiedzialność przedsiębiorstw a ich wyniki ekonomiczne - aspekty teoretyczne, „Przegląd Organizacji”, nr 10, s.7-10.

18 Julewicz A., Ejdys J. (2009), Korzyści spotecznej odpowiedzialności biznesu, „Ekonomika i Organizacja Przedsiębiorstwa", nr 6, s.181-191.

19 Dymowski J., Szymańska M. (2009), CSR raport specjalny. Spoteczna odpowiedzialność biznesu, „Brief”, nr 2.
} 
Also R.W. Griffin puts forward the following arguments for social responsibility:

- economic activity creates problems, which is why enterprises should participate in their resolution,

- enterprises are also social groups,

- enterprises have the necessary resources to solve social problems,

- enterprises are partners in the economy, just like government and society ${ }^{20}$.

Opponents of the idea of corporate social responsibility argue that expanding its interpretation can threaten the economy, diverting from the basic calling of profit-making for owners. Voices against the concept of corporate social responsibility also appear in Poland before it reached full maturity, which is a big problem and a phenomenon harmful to business.

Some advocate the thesis that CSR is no longer fashionable and one should look for something more effective and effective, which will bring more tangible benefits. However, it should be remembered that there is no way to talk about fashion when it comes to implementing principles that are friendly to the company and its employees, the environment, and society.

Currently, business is increasingly faced with the need for transparency and to inform stakeholders about its activities. Information is desirable by the public because it concerns issues such as the environmental impact of manufactured goods, integrity in maintaining good quality goods and services. What's more, disclosure of irregularities in terms of ethical principles, corporate responsibility on the market reduces confidence in stakeholders and even breaks business contacts. Therefore, defining the company's stakeholders and a systematic striving to meet their needs and expectations is an important element. On the other hand, the company must meet the expectations of other groups to best achieve its own goals and tasks.

However, it turns out that not all researchers are optimistic about the concept of CSR towards the sector of micro, small and medium enterprises. The authors, P. Raynard and M. Forstater emphasize that the benefits of implementing CSR principles in the SME sector are much smaller than in large companies or corporations. Smaller business entities have more problems with mastering standards and implementing CSR policy, they do not have recognizable brands, they lack knowledge and time to cooperate with local communities, organizations, or institutions ${ }^{21}$.

On the other hand, changes and globalization force greater care in understanding the principles of sustainable development for all entities, including the SME sector.

It is true that this sector, like large companies, does not function in isolation from the surrounding communities and the ability of companies to compete depends precisely on the conditions in the areas in which they operate.

\footnotetext{
Griffin R.W. (2004), Podstawy zarządzania organizacjami, WN PWN, Warszawa.

21 Raynard P., Forstater M. (2002), Corporate Social Responsibility: Implications for Small and Medium Enterprises in Developing Countries, UNIDO, s.116-126.
} 
The competitive strength of companies today depends on the efficiency with which they use their labor resources, capital, and natural resources to produce high-quality goods and services. Productivity depends on having well-educated and healthy employees who feel safe, live in decent conditions, and are motivated to make efforts for the company.

It turns out that for both large and small enterprises, the competitive context consists of four essential and interdependent elements of the local business environment that affect performance. These are: firstly, the availability of means of production, i.e. the ability to recruit qualified employees, the presence of technical infrastructure, transparent and effective administrative processes. Secondly, demand factors, i.e. the size of the local market, compliance of product standards with local standards and the level of education of local buyers. To a large extent, the level of implementation of CSR principles, as well as pressure to promote innovation depends on the awareness of buyers. Thirdly, the rules of competition, i.e. conditions and regulations that should ensure the protection of intellectual property or the fight against corruption because the elimination of negative phenomena promotes the development and increases the attractiveness of a given area for business. Fourthly, related, and supporting industries (suppliers, cooperators). Enterprise productivity can also increase due to the existence of a strong base in the form of suppliers of high-quality services and entire industries that support a specific type of business. The closeness and trust of business partners facilitate the exchange of information and innovation. It is convenient to cooperate with nearby suppliers and service providers. Responsible and ethical actions, regardless of the size of the company, contribute to creating trust in business. Often, creating trust is long-lasting and you have to "earn" it, but in the long run, it connects with predictability, diligence, and responsibility ${ }^{22}$.

\section{Knowledge management and CSR in family businesses, the aspect of employees}

Given the lack of willingness to exchange knowledge between entities in family businesses, the level of trust is still low. On the other hand, family business entities are not able to carefully divide knowledge that they can share in cooperation and knowledge of strategic importance, which is a source of competitive advantage.

According to the authors of the Future Work Skills 2020 research project, six key changes shape contemporary working conditions and business operations.

The first area is the development of intelligent machines and systems. In companies, the use of machines and software are becoming the norm, thanks to which employment can be reduced or employees can be moved to more creative work by replacing simple work with machinery.New media are emerging, new ways of communicating requiring digital competence beyond ordinary language $e^{23}$.

\footnotetext{
22 Marcinkowska M. (2010), Spoteczna odpowiedzialność przedsiębiorstw a ich wyniki ekonomiczne-aspekty teoretyczne, „Przegląd Organizacji”, nr 10, s.7-10.

23 Jaska E., Stawicka E., Werenowska A. (2019), Wykorzystanie mediów spotecznościach w kreowaniu wizerunku podmiotu prawnego, w: Samorząd, marketing terytorialny a media, Jaska E., Skoczek (red.), s.181-200.
} 
Electronic media, social media, and instant messengers require an immediate response. There is a choice of information and the use of mental shortcuts. A new group of stakeholders is emerging that family businesses are often not even familiar with. They can be positively involved - actively and positively engage in the development of the enterprise, most often they are employees, clients, contractors, and the local community. Negatively involved, when they are actively and negatively involved in the development of an enterprise, they can be characterized by aversion to organization, hostile reactions, e.g. caused by communication errors, competitors, suppliers, contractors, and the local community. Or even fictitious stakeholders - fake owners creating fake online accounts, profiles, most often disseminate bad reviews and fake messages ${ }^{24}$.

Another issue is big data related to a large or even huge amount of data collected in electronic devices in combination with the currently available computing power of computers. It allows you to create algorithms, profiles, segmentations, and make decisions on this background. Family businesses have a problem with this - misunderstandings. In the world of traditional business and often just in family businesses, customers are very loyal, sometimes out of necessity rather than by choice. Convenient location, information asymmetries, and good neighborly relations mean that the mediocrity of the products and the poor level of services are often dry. The development of the Internet means that the market for substitutes is developing, which in turn can eliminate the need for hitherto "poorly" fulfilled needs, for example by unsuccessful family businesses. It should be assumed that proper response to changes in the company's environment and response becomes necessary. It turns out that in the company knowledge workers, their efficiency and scope of relationships are the most valuable factor determining adaptation abilities. In family businesses, the problem is the employment of employees with a high level of human capital, as well as the lack of employees with ICT skills (information and communication technologies). It turns out that sincere intentions and the atmosphere of a family home at work are no longer enough in the fight for real employee talents on the market. There is a lack of modern methods of recruiting, motivating, and appreciating the employee. In family businesses, tradition is combined with the competencies of the future. However, not all companies can understand and keep up with this mix.

Another factor of change is the aspect of the extension of professional activity and new employee career models. Society is aging and more and more employees over 50 years old are working in companies. Family businesses are often employees who have co-created businesses with their owners from scratch. Too little in family businesses there are issues of diversity and knowledge from around the world. A relatively new aspect of employing foreigners, especially employees from Ukraine in Poland, emphasizes the inability to deal with diversity management ${ }^{25}$.

24 Luoma-Aho V. (2015), Understanding Stakeholder Engahgement: faith folders, hateholders and fakeholders, "Research Journal of the Institute for Public Relations", Nr 1.

25 Stawicka E. (2019), Zarzadzanie różnorodnością a internacjonalizacja jako element efektywnego funkcjonowania przedsiębiorstwa, w: R. Tomaszewska (red.), Sekrety organizacji, Barwy codzienności, Bydgoszcz, s.111-136. 
The necessity to attract new employees as key challenges is increasingly clear in family businesses. There has long been a dilemma regarding the employment of people in family businesses as well as disorders such as nepotism or cronyism. The fluctuations regarding succession and the reluctance to transfer the family business in the management of outsiders are also emphasized. Statistics on family businesses show that about $30 \%$ of companies pass into the hands of the second generation, $15 \%$ under the rule of the third generation, while only $3 \%$ of companies go to the next generations ${ }^{26}$. As G. Ignatowski emphasizes, the phenomenon of nepotism is widespread in Poland. This causes negative opinions, poorly received by other employees, especially by people with higher education. The biggest consequences of nepotism include financial losses due to employing people who are not competent ${ }^{27}$.

Consequently, instead of gaining in family businesses, the following may appear:

- limiting employee motivation;

- increased staff responsibilities and, consequently, reduced service quality;

- quitting the best employees, specialists and people with a lot of knowledge ${ }^{28}$.

Super organizational structures are another factor in the changes that shape modern working conditions. The development of community technologies affects the way work is done, including production and distribution, products are designed in another country, production occurs in another country, and distribution can also be carried out in different markets. New states and global challenges such as climate change or pandemics will probably also verify these market behaviors. It is reasonable how family businesses will react to this type of turmoil. They may strengthen even more in local markets, where economic patriotism is increasingly emphasized. This can cause even greater anchoring and lack of innovation, or on the contrary, can force innovation.

The aspect of the globally connected world is also puzzling, which trend marked the development of the end of the 20th and the beginning of the 21st century. The characteristics of modern globalization leave no illusions about the reversibility of this process. It slows down or even stops, as it was after the terrorist attack of September 11, 2001, on the World Trade Center, then in 2007-2009 during the financial crisis caused by a lack of ethics in banking, and in 2020 during the new danger of a global pandemic disease crown virus (COVID -19). However, it is difficult to imagine a reversal of globalization trends. You can only try to solve the dilemmas associated with it and take on ethical challenges ${ }^{29}$.

Attention should also be paid to the validity of the ten determinants highlighted by the Institute for the Future, which were defined in the Future Work Skills 2020 Report $^{30}$.

26 Gołaszewska-Kaczan U., Grześ A. (2014), Możliwość wykorzystania nowoczesnych form szkolenia w firmach rodzinnych, „Przedsiębiorczość i Zarządzanie”, Wydawnictwo SAN, Tom XV, Zeszyt 7, Część III, s.149-159.

27 Ignatowski G. (2016), Familizm i nepotyzm: rodzina w firmach rodzinnych, „Przedsiębiorczość i Zarządzanie”, t. 17, z. 6, Firmy rodzinne - wyzwania wspótczesności, s.181-191.

28 Wypych- Dobkowska M. (2010), Konsekwencje nepotyzmu w organizacjach, Zeszyty Naukowe Wyższej Szkoły Ekonomii i Informatyki, z. 5, $\mathrm{Nr} 6$, s.9-20.

29 Dembiński P. (2011), Finanse po zawale. Od euforii finansowej do gospodarczego ładu, Studio Emka, Warszawa.

30 http://www.iftf.org/uploads/media/SR-1382A_UPRI_future_work_skills_sm.pdf, 4.06.2020. 
Therefore, the key aspect is the ability to find a deeper meaning and sense of things, to perceive meaning that cannot be seen at first glance. Scientists called this inference. For example, M. Fabjański ${ }^{31}$ describes it as a competence of the future straight from ancient philosophy. The author notes that reasoning, as well as unconventional adaptive thinking and coping with information overload, are typical subjects of philosophical training called in the antique "control over internal speech". Also, social intelligence is referred to as empathy, ease of entering into relationships with other people, stimulation of desired reactions and attitudes is a competence that helps to gain trust. Another is unconventional adaptive thinking. Agility in thinking and going out of the box. It is a also quick and good reactions to changes.

An important issue raised by specialists from the Institute for Future is intercultural competence. Ability to function and behave in different cultural environments. As previously mentioned, also employing workers from other socio-cultural areas, foreigners, but also people of a different origin, outsourcing to other countries. Data synthesis is a significant competence. The weakness of family businesses is emphasized. The ability to compile large batches of data to obtain knowledge. It is similar to the competence of the ability to critically assess information circulating in the media and adapt them to the specifics of your company. Proficiency in understanding and combining the meanings of concepts from various fields, i.e. multidisciplinarity.

Design thinking is another development competence. Intuition, working methods, innovations, translating complex models into your own organizational culture. There is a gap in the literature on the subject in research and the organization of organizational culture in family businesses. There is no acceptance of the characteristics of organizational culture as is the case with large companies or corporations. It also involves the competence of dealing with information overloading. The ability to select the right meanings, information, and data that would contribute to achieving the company's benefits. At the end of key competencies, the tenth was the cooperation of virtual teams. Ability to cooperate and engage in work via messengers, virtual platforms, or virtual drives.

According to A. Barańska's research indicates that in a group of 82 family businesses, as much as $60 \%$ declared that if the implementation of a project or task lacks adequate knowledge in the enterprise, the desired knowledge is sought outside, external partners are sought. However, in the next question regarding the acquisition of new knowledge when employing employees, the respondents indicated that there is no special recruitment and search for talent because the company usually employs a person recommended by family or friends (68\% of respondents). Research in the field of family businesses in Poland also indicates that the self-esteem of family businesses as to their position in the industry is high. About $30 \%$ of the surveyed companies declared that they have a strong market position and will continue to implement their activities on the market without changes, it

31 Fabjański M. (2017), Uwolnij się! Dobre życie wedtug siedmiu filozofów-terapeutów, „Znak”, 29.03.2020. 
was emphasized in these companies that there is no threat from competition. About $50 \%$ of family business entrepreneurs confirmed that they are doing well now, but changes are needed if one wants to maintain a stable market position. On the other hand, the remaining $20 \%$ feel threatened on the market, do not yet know what could be improved and are even considering leaving the market ${ }^{32}$.

Future competencies and knowledge influence the formation of entrepreneurial attitudes and strategies. Knowledge and competencies shape the so-called intellectual entrepreneurship. In summary, family entrepreneurship includes "opportunity-based" and "forced" entrepreneurship based on necessity. Opportunity-based entrepreneurship is a company with a clearly defined vision, whose owners consistently strive to achieve it. Forced entrepreneurship is undertaken from the necessity of supporting the family and seeking financial resources. This approach is characterized by passivity. Opportunity-based entrepreneurship means greater growth dynamics and a chance for success ${ }^{33}$.

A family enterprise is a combination of social - family and economic - enterprise ${ }^{34}$. Family businesses play an active and pivotal role in global economic growth ${ }^{35}$. In emerging economies, family businesses are particularly important because they show stronger dynamics and versatilities ${ }^{36}$, perform unique tasks such as wealth preservation ${ }^{37}$, and account for a higher proportion of national economic growth ${ }^{38}$. Using a multi-year definition, family businesses were recognized as managed and/or managed companies intending to shape and/ or realize the vision of a company run by a dominant coalition of the same family or a small number of families in a way that can sustain a business over generations of the family ${ }^{39}$.

The features of a family business are a specific organizational culture, family atmosphere, flexibility, and knowledge of social problems. Characteristic is the family's social capital, i.e. a culture of cooperation, shared experiences, loyalty, readiness for sacrifices and sacrifices, empathy ${ }^{40}$. According to CBOS (2016) data, we trust people and companies from the immediate sphere the most, only $1 / 3$ of respondents trust large companies ${ }^{41}$.

32 Barańska A. (2016), Pozyskiwanie wiedzy przez firmy rodzinne (wyniki badań), w: J. Klimek, B. Żelazko, Zarzadzanie firma rodzinna - wybrane zagadnienia, OW SGH, Warszawa, s.124.

33 Keyt A., McCann G. (2020), Manganing the family, "Family business", https://www.thebalancesmb.com, dostęp 31.03.2020, s.73.

34 Sułkowski Ł., Maryjański A. (2009), Firmy rodzinne: jak osiagną́ sukces w sztafecie pokoleniowej, Warszawa, s.95-116.

35 Claessens S. i in. (2002), Disentangling the incentive and entrenchment effects of large shareholdings, „Journal of Finance", 57(6), 2741-2772.

36 Whyte M.K. (1996), The Chinese family and economic development: Obstacle or engine?, "Economic Development and Cultural Change", 45(1), s.130.

37 Carney M. (2007), Minority family business in emerging markets: Organization forms and competitive advantage, „Family Business Review”, 20(4), 289-300.

38 Claessens S., Djankov S., Fan J.P.H., Lang L. (2002), Disentangling the incentive and entrenchment effects of large shareholdings, ,Journal of Finance”, 57(6), 2741-2772.

39 Charles E., Stevens E., Roland E. Kidwell, R. Sprague (2015), Bound by Laws, or by Values? A Multi-Leveland Cross-National Approach to Understanding the Protection of Minority Owners in Family Firms Corporate Governance, "An International Review", 23(3), s.203-215.

40 Popczyk W. (2014), Kapitat spoteczny w firmach rodzinnych. Struktura i mechanizm kreowania kapitatu rodziny, „Przedsiębiorczość i Zarządzanie”, XV, z. 7, s.138.

${ }^{41}$ CBOS (2016), Zaufanie spoteczne, Warszawa. 
At the same time, small family businesses are seen as conservative, less susceptible to new products, with financial constraints. The problem is obtaining and employing welleducated employees and high-quality human capital. There is no strategic management in family businesses, activities are current, disordered, random. They work intuitively, do not create a mission, vision or strategy ${ }^{42}$.

As indicated by A. Barańska, family businesses generally cannot afford to buy knowledge. They do not have financial resources, they cannot afford training, they do not carry out market research, they are not able to guarantee attractive employee remuneration, there are no additional benefits in these companies. Also taking over the company by successors is often associated with the transfer of the basis for the functioning of the company, knowledge developed by seniors ${ }^{43}$.

For example, J. Wiśniewska-Mikosik distinguishes seven types of family businesses:

- with strong parental supervision,

- looking to the future,

- about dominant owners,

- benefiting from 'internal help',

- run by mother and father,

- large family businesses,

- run by siblings ${ }^{44}$.

In the literature on the subject, it is difficult to find diagrams of the organizational culture of small businesses, as in the case of large companies or corporations. So, if in family companies we are dealing with similar components of organizational culture, it is only theoretically subject to similar definitions, in practice, the interpretation is very diverse. In addition, in socialist countries such as Poland, the property of the past system was the liquidation of private property. Few family businesses have a longer history than 30 years. Currently, over $70 \%$ of enterprises in the European Union are family businesses ${ }^{45}$. A family business, however, is specific knowledge. Effective knowledge management determines competitive advantage. In family businesses, you can often emphasize the existence of tacit knowledge, unique and uncoded knowledge. The family accumulates it over time, develops it, transfers it between generations, and protects it so that it does not leak to the competition $^{46}$.

42 Stawicka E. (2017), Spoteczna odpowiedzialność i rozwój koncepcji work-life balance w zarzadzaniu organizacją, w: J. Klimek, B. Żelazko (red.), Wybrane paradygmaty zarzadzania firmami rodzinnymi, Oficyna Wydawnicza SGH, s.83-94.

43 Barańska A. (2016), Pozyskiwanie wiedzy przez firmy rodzinne (wyniki badań), w: J. Klimek, B. Żelazko, (red.), Zarzadzanie firma rodzinna - wybrane zagadnienia, Oficyna Wydawnicza SGH, s.124.

44 Wiśniewska-Mikosik J. (2016), Konsekwencje obecności kultury organizacyjnej w przedsiębiorstwach rodzinnych $w$ Polsce, w: Ł. Sułkowski, A. Marjański (red.), Firmy rodzinne - wspótczesne nurty badań i praktyki zarzadzania, „Przedsiębiorczość i Zarządzanie”, Tom XV, Zeszyt 7, Część III, Łódź, s.61-73.

45 Ciaiana P., Pokrivcakband J., Drabik D. (2009), Transaction costs, product specialization and farm structure in Central and Eastern Europe, "Post-Communist Economies", Vol. 21, No. 2, June, s.191-201.

46 Miller D., Le Bretoniller I. (2005), Managing for the long run: Lesson in competitive advantage from great family business, MA: Harvard Business School Press, Boston. 
When it comes to acquiring knowledge by family businesses, most often it is participation in industry fairs, support of external experts, cooperation with other entities, training and hiring a new employee, i.e. knowledge emerging with new human capital ${ }^{47}$.

Generally, the more knowledge in a company, the easier it is to obtain information. The opportunity to employ better - educated employees and access to technology and information affect the acquisition of knowledge. It depends on the people employed in family businesses whether their ingenuity and obtaining information creates solutions and innovations without the involvement of significant resources. Family businesses often learn in a non-standard way, using the knowledge of industry leaders. Leaders gain the greatest advantage, as they are the first to recognize opportunities and threats using knowledge in practice. Unfortunately, nowadays, when clients provide companies with more and more knowledge, the task of managers is assimilation and integration. Companies that can to turn knowledge in the minds of their employees and clients (human capital) into practical possibilities (structural capital) and relationships (relationship capital) become leaders.

Based on the research carried out by A. Barańska on a sample of 82 family businesses, family entrepreneurs declare that they are looking for new knowledge. Over $70 \%$ of respondents are looking for new knowledge on the Internet and trade press. The source of knowledge was also the advice of family members or friends. A very small group, around $40 \%$ of respondents benefited from paid consultations with experts. Regarding acquiring knowledge during courses and training, even though $72 \%$ declared their willingness to participate, the actual involvement in this type of activity varied. Acquiring knowledge in the form of cooperation with external partners is also a problem. A small number of family businesses make alliances and work with other entities to acquire knowledge and improve development. Obtaining information yourself is long and costly and cooperation could be a good way to expand your knowledge quickly and cheaply. Very often in family businesses, an interesting idea is abandoned than cooperation with other companies. Most often, family businesses rely on observing industry leaders and imitating their solutions ${ }^{48}$.

Research on competencies in family businesses has highlighted several opportunities and threats. Polish family businesses focus on management, finances, and HR, while they do not take action in terms of digital competencies. Research shows that family businesses that declare that the phenomenon of big data affects them to a high or very high degree constitute about $43 \%$ of the surveyed companies. It should be noted that so declared the leaders of family businesses, i.e. the largest family enterprises using the "Family Tree Company" sign, whose turnover exceeded the median average turnover for all 500 family businesses with a tree, or over 7388.9 thousand. PLN (63 companies from 202). The second group, i.e. 139 companies, recognized as other family businesses replied that big

Vega-Jurado J., et al. (2008), Analyzing determinants of firms absorptive capacity, "R\&D Management", Vol. 38, No 4, s.401.

48 Barańska A. (2016), Pozyskiwanie wiedzy przez firmy rodzinne (wyniki badań), w: J. Klimek, B. Żelazko (red.), Zarządzanie firma rodzinna - wybrane zagadnienia, Oficyna Wydawnicza SGH, s.124. 
data was about them, but not definitely, only $24 \%$ of this group of enterprises noticed the presence of this phenomenon ${ }^{49}$.

Entrepreneurs, when asked about the acquisition of financial planning competencies, declared that they had acquired these competencies at a high and very high level. Almost $80 \%$ of family business leaders and $51 \%$ of entrepreneurs in other family businesses responded. On the other hand, the respondents drew attention to the most desirable competence in their opinion, which was social intelligence. They also definitely pointed to the gaps in knowledge in the field of future competences ${ }^{50}$.

\section{Implementation of good CSR practices in the area of employees in the practice of Polish enterprises}

In Poland, we are dealing with a relatively "young" market economy. During the communist period, the figure of the capitalist entrepreneur was received rather negatively. After the fall of communism, Poland entered a phase of transformation. Confidence in entrepreneurs remained at a very low level for many years. After accession to the European Union, other possibilities also appeared. Many designs appeared along with international corporations that brought their standards and culture. Gradually, benchmarking gained importance. More and more examples of good practices in the field of environmental protection, internationalization of ecological values, observance of human rights, and prevention of discrimination against employees have been developed. Observation of trends in the behavior of market entities. This leads to the need to shape new rules and enforce them, legal regulations, and also to obtain certificates at the international level. It turns out that entrepreneurs who observe and implement new and effective solutions faster gain a competitive advantage in the market faster. Good practices and examples of company leaders have gained special significance in Poland. An example is good CSR practices, i.e. companies' actions aimed at positive effects in the company and its environment. The importance of benchmarking in the application of CSR principles among Polish companies is indicated by the data of the Responsible Business Forum. Data on the number of good practices over the years 2008-2019 increased from year to year by about 30\%. In 2018, 177 companies reported to the Report of Responsible Companies, presenting 639 new good practices and 551 examples of long-term practices. In 2019, however, there were 185 new practices, 288 long-term practices, 122 enterprises reported good practices in the field of employees. Most good practices concerned social involvement and local community development. Many good practices developed in the area related to the environment. Entrepreneurs are increasingly observing good practices regarding closed-loop practices, solutions for reducing $\mathrm{CO} 2$, and saving energy and water. They are also encouraged by the good results of other entrepreneurs ${ }^{51}$.

However, more and more importance is attached to workplace practices. In the era of

FFR (2017), Kompetencje przysztości w firmach rodzinnych, Fundacja Firmy Rodzinne, Warszawa.

Ibidem.

51 FOB (2008-2019), Raport dobrych praktyk 2008-2019, Warszawa. 
problems with employees, employers reasonably begin to imitate other entrepreneurs and strive for good employees by creating facilities for them. Practices in this area relate to solutions rarely undertaken before: solutions that favor young parents, practices that help maintain life balance, and support the fight against stress.

In 2018, there were 129 companies out of 177 registered that declared changes in good work practices as a result of benchmarking. In comparison with 2008 to 2019, the number of good work practices was very high (16 apprenticeships in 2008 to 288 in proportion to $2019)^{52}$.

One of the important elements of building employees' commitment is a sense of agency, the ability to take action, take the initiative that is appreciated in the company. The number of examples of such solutions in companies is growing. The popularity of innovation reporting systems or competitions for the most active employees. Some organizations introduce the possibility of a direct conversation or asking questions to the president. The number of internships in employee training and development is increasing.

Organizations improve working conditions, encourage volunteering, and care for safety. Employers significantly improve the approach to good employee health and quality of life.

As the Responsible Business Forum indicates, the implementation of solutions from various areas of business activity results from observations of the best. Generally, typical of Polish entrepreneurs is the lack of strategic management. Undertaking more radical solutions is usually a consequence of previous observations, for example, of the successes of competition, the proverbial "neighbor" ${ }^{3}$. In the Business Leaders Forum publications from 1999, you could read the first in Polish inspirational statements of CEOs and managers from companies such as Levi Stauss, Body Shop, or BP about the role of business in society. Good practices have been developing successively. Enterprises are looking for solutions and responsible practices because consumer interest in company practices is also increasingly common.

The increasing number of solutions towards employees is the result of benchmarking. The best employees want to work in responsible companies and entrepreneurs were forced to observe the best practices, how to retain a valuable employee. In this case, benchmarking is about comparing with the best organizations, learning from them the principles, methods, or even methods of managing a company, and then implementing improvements and improving patterns in their activities. Emphasis on benchmarking can be seen in the statements of market leaders and practitioners. In benchmarking, entrepreneurs can draw patterns not only from companies operating in the same industry but also can apply solutions implemented by leaders of other industries.

Especially in the case of smaller companies, observing competition is of educational importance. Acquiring knowledge and better knowledge management in family businesses would be a better solution. This applies to both management and employees.

FOB (2020a), Raport dobrych praktyk 2019, Warszawa.

53 FOB (2020b), Company readiness for inclusive workforce transitions, http://odpowiedzialnybiznes.pl/, dostęp: 07.06.2020. 
The aspect of achieving sustainable development goals, in this case, Goal 8, should improve the functioning of family businesses, influence the innovation of these enterprises and build an advantage in the markets.

Ten key trends related to broadly understood human capital have been identified in the Global Human Capital Trends research. The main emphasis was placed on the growing importance of the need for an individualized approach to employees, both in terms of career paths, work models focused on new challenges and experiences, as well as satisfying non-professional needs (spiritual development, social activity) ${ }^{54}$. New trends in good work practices are confirmed by the Sustainable Development Goals. The importance of the existence of health and safety programs at work, aspects of economic growth and decent work as well as increasing awareness of education, knowledge development, competencies and knowledge management in enterprises are emphasized.

\section{Conclusion}

The above theoretical analysis is a contribution to detailed research on the social responsibility of family enterprises with employees in the aspect of sustainable development and practical terms. Family businesses are increasingly striving to manage knowledge, shape an informed strategy based on proper knowledge, competencies, information, and motivate employees to act in a way that will improve the efficiency of the organization. An interdisciplinary approach to achieving organizational goals through the use of knowledge. The policy of sustainable goals is gaining importance, which assumes not leaving anyone behind. National strategies for implementing SDGs in the implementation of Objective 8 related to decent work and economic growth are still under development.

Employees' opinions on the reputation of enterprises are also significant. Many reports and rankings indicate that employee opinions are one of the main reasons for taking action for sustainable development. Bearing in mind the guidelines and recommendations regarding the implementation of Objective 8 in practice, it is reasonable to conduct further in-depth research on work practices in the context of achieving the Sustainable Development Goals in family businesses. Cooperation with other family businesses and exchange of practices regarding problems and/or progress in improving employee qualifications can be an effective way to change the attitude of the company and its employees to think about the future of work and the implementation of CSR.

Firms should have a structured HR action plan to respond in the most constructive way possible to evolving megatrends, rather than acting in an ad hoc manner.

Employers should consider the development and adaptation of the skills matrix to identify what skills the company needs now and in the future.

Entrepreneurs should encourage employees to train in soft skills is just as important as hard skills. Importantly, companies should provide special training for employees.

Companies should improve internal communication with employees from groups at risk of exclusion to get to know their perspective regarding the role they play in the

${ }^{4}$ Deloitte (2018), Deloitte Global Human Capital Trends, https://www2.deloitte.com.pl, dostęp: 06.06.2020. 
organization and whether, for example, they expect competence development in a specific direction.

\section{References:}

1. Agenda 2030 (2020), Serwis Rzeczypospolitej Polskiej, https://www.gov.pl/web/rozwoj-pracatechnologia/agenda-2030, data dostępu: 4.06.2020.

2. Barańska A. (2016), Pozyskiwanie wiedzy przez firmy rodzinne (wyniki badań), w: Zarządzanie firma rodzinna - wybrane zagadnienia, J. Klimek, B. Żelazko (red.), Oficyna Wydawnicza SGH, Warszawa, s.124.

3. Carney M. (2007), Minority family business in emerging markets: organization forms and competitive advantage. „Family Business Review”, 20(4), s.289-300.

4. Caroll A.B. (1991), The Pyramid of Corporate Social Responsibility: Toward the Moral Management of Organizational Stakeholders, "Business Horizons".

5. CBOS (2016), Zaufanie spoteczne, Warszawa.

6. Charles E., Stevens E., Roland E. Kidwell, R. Sprague (2015), Bound by Laws, or by Values? A MultiLeveland Cross-National Approach to Understanding the Protection of Minority Owners in Family Firms Corporate Governance, "An International Review”, 23(3), s.203-215.

7. Ciaiana P., Pokrivcakband J., Drabik D. (2009), Transaction costs, product specialization and farm structure in Central and Eastern Europe, "Post-Communist Economies", Vol. 21, No. 2, June, s.191-201.

8. Claessens S., Djankov S., Fan J.P.H., Lang L.H.P. (2002), Disentangling the incentive and entrenchment effects of large shareholdings, „Journal of Finance”, 57(6), 2741-2772.

9. CSR Consulting (2016), SDGs w praktyce, CSR Consulting, Warszawa, s.5.

10. Deloitte (2018), Deloitte Global Human Capital Trends, https://www2.deloitte.com.pl, dostęp: 06.06.2020.

11. Dembiński P. (2011), Finanse po zawale. Od euforii finansowej do gospodarczego tadu, Studio Emka, Warszawa.

12. Dymowski J., Szymańska M. (2009), CSR raport specjalny. Spoteczna odpowiedzialność biznesu, „Brief”, nr 2.

13. Fabjański M. (2017), Uwolnij się! Dobre życie wedtug siedmiu filozofów-terapeutów, „Znak”.

14. FFR (2017), Kompetencje przysztości w firmach rodzinnych, Fundacja Firmy Rodzinne, Warszawa.

15. FOB (2008-2019), Raport dobrych praktyk 2008-2019, FOB, Warszawa.

16. FOB (2020a), Raport dobrych praktyk 2019, FOB, Warszawa.

17. FOB (2020b), Company readiness for inclusive workforce transitions, http://odpowiedzialnybiznes.pl/, dostęp: 07.06.2020.

18. Gerlach R. (2019), Organizacja przysztości w perspektywie czwartej rewolucji przemystowej i spoteczeństwa 5.0, w: Barwy codzienności, R. Tomaszewska (red. nauk.), UKW, Bydgoszcz, s.63.

19. Gołaszewska-Kaczan U., Grześ A. (2014), Możliwość wykorzystania nowoczesnych form szkolenia w firmach rodzinnych, „Przedsiębiorczość i Zarządzanie”, Wydawnictwo SAN, Tom XV, Zeszyt 7, Część III, s.149-159.

20. Griffin R.W. (2004), Podstawy zarzadzania organizacjami, WN PWN, Warszawa.

21. Ignatowski G. (2016), Familizm i nepotyzm: rodzina w firmach rodzinnych, „Przedsiębiorczość i Zarządzanie, t. 17, z. 6, cz., Firmy rodzinne - wyzwania wspótczesności, s.181-191. 
22. Jaska E., Stawicka E., Werenowska A. (2019), Wykorzystanie mediów spotecznościach w kreowaniu wizerunku podmiotu prawnego, w: Samorzad, marketing terytorialny a media, Jaska E., Skoczek (red.), Warszawa, s.181-200.

23. Julewicz A., Ejdys J. (2009), Korzyści spotecznej odpowiedzialności biznesu, „Ekonomika i Organizacja Przedsiębiorstwa”, nr 6, s.66-74.

24. Keyt A., McCann G. (2020), Manganing the family, "Family business", https://www.thebalancesmb. com, dostęp 31.03.2020, s.73.

25. Kukla D. (2016), Wspótczesne spoteczeństwo w kontekście kreowania rynku pracy, "Szkoła, Praca, Zawód”, nr 11, Bydgoszcz, s.63-72.

26. LBG (2014), Guidance manual from inputs to impact-measuring corporate community contributions through the $L B G$ framework, "Corporate Citizenship”, Londyn.

27. Lewandowska-Akhvlediani S. (2011), CSR a cztowiek jako jednostka, w: Ustugi spoteczne odpowiedzialnego biznesu, Bonikowska, Grewiński (red.), Wyższa Szkoła Pedagogiczna, Warszawa, s.106-153.

28. Liczmańska-Kopcewicz K., Mizera K., Pypłacz P. (2019), Corporate Social Responsibility and Sustainable Development for Creating Value for FMCG Sector Enterprises, “Sustainability”, 11(20), s.5808.

29. Luoma-Aho V. (2015), Understanding Stakeholder Engahgement: faith folders, hateholders and fakeholders, "Research Journal of the Institute for Public Relations", Nr 1.

30. Łukasiński W. (2010), Aspekt ekologiczny w koncepcji spotecznej odpowiedzialności przedsiębiorstwa, „Ekonomika i Organizacja Przedsiębiorstwa”, nr 10, s.10-18.

31. Marchlewicz M. (2020), 5 lat SDGs w Polsce, raport Odpowiedzialny Biznes w Polsce 2019, FOB, Warszawa, s. 1430 .

32. Marcinkowska M. (2010), Spoteczna odpowiedzialność przedsiębiorstw a ich wyniki ekonomiczne - aspekty teoretyczne, „Przegląd Organizacji”, nr 10, s.7-10.

33. Meehan K., Richards A. (2006), Corporate Social Responsibility, The 3C-SR model, "International Journal of Social Economics”, Vol. 33, Nr 5/6, s.392.

34. Miller D., Le Breton-iller I. (2005), Managing for the long run: Lesson in competitive advantage from great family business, MA: Harvard Business School Press, Boston.

35. PN-ISO 26000 (2012), Wytyczne dotyczące spotecznej odpowiedzialności, PKN, Warszawa, listopad.

36. Popczyk W. (2014), Kapitat spoteczny w firmach rodzinnych, Struktura i mechanizm kreowania kapitatu rodziny, „Przedsiębiorczość i Zarządzanie”, XV, z. 7, s.138.

37. Raynard P., Forstater M. (2002), Corporate Social Responsibility: Implications for Small and Medium Enterprises in Developing Countries, UNIDO, s.116-126.

38. Stawicka E. (2017), Spoteczna odpowiedzialność i rozwój koncepcji work-life balance w zarządzaniu organizacją, w: Wybrane paradygmaty zarządzania firmami rodzinnymi, J. Klimek, B. Żelazko (red.), Oficyna Wydawnicza SGH, s.83-94.

39. Stawicka E. (2019), Zarządzanie różnorodnościq̨ a internacjonalizacja jako element efektywnego funkcjonowania przedsiębiorstwa, w: Sekrety organizacji, Barwy codzienności. R. Tomaszewska (red.), Bydgoszcz, s.111-136.

40. Strykowska M. (2001), Globalizacja a kariera zawodowa, w: Spoteczne problemy globalizacji, Z. Blok (red.), WN UAM, Poznań, s.43-44.

41. Sułkowski Ł., Maryjański A. (2009), Firmy rodzinne: jak osiągnąć sukces w sztafecie pokoleniowej, Warszawa, s.95-116. 
42. Stevens C.E., R.E. Kidwell, R. Sprague (2015), Bound by Laws or by Values?, A Multi-Leveland CrossNational Approach to Understandingthe Protection of Minority Owners in Family Firms Corporate Governance, "An International Review”, 23(3), s.203-215.

43. Wartick S.L., Cochran P.L. (1985), The evolution of the Corporate Social Performance Model, "Academy of Management Review", Vol. 10, Nr 4, 1985.

44. Wiśniewska-Mikosik J. (2016), Konsekwencje obecności kultury organizacyjnej w przedsiębiorstwach rodzinnych $w$ Polsce, w: Firmy rodzinne - wspótczesne nurty badań i praktyki zarządzania, Ł. Sułkowski, A. Marjański (red.), „Przedsiębiorczość i Zarządzanie”, Tom XV, Zeszyt 7, Część III, Łódź, s.61-73.

45. Whyte M.K. (1996), The Chinese family and economic development: obstacle or engine? "Economic Development and Cultural Change", 45(1), s.130.

46. Wood D.J. (1991), Corporate Social Performance Revisited, “Academy of Management Review”, Nr 4, 1991.

47. Wypych- Dobkowska M. (2010), Konsekwencje nepotyzmu w organizacjach, Zeszyty Naukowe Wyższej Szkoły Ekonomii i Informatyki, z. 5, Nr 6, s.9-20.

48. Vega-Jurado J., et al. (2008), Analyzing determinants of firms absorptive capacity, "R\&D Management", Vol. 38, No 4, s.401.

Ewa Stawicka, Management Institute, Warsaw University of Life Sciences (WULS), Ewa_stawicka@sggw.edu.pl 